\title{
Ultrasound-assisted lipase-catalyzed synthesis of D-isoascorbyl palmitate: process optimization and Kinetic evaluation
}

Feng-Jie Cui ${ }^{1,3^{*}}$, Hong-Xia Zhao ${ }^{1}$, Wen-Jing Sun ${ }^{1,2,3^{*}}$, Zhuan Wei ${ }^{4}$, Si-Lian Yu ${ }^{2,3}$, Qiang Zhou ${ }^{2,3}$ and Ying Dong ${ }^{1}$

\begin{abstract}
Background: D-isoascorbic acid is a food antioxidant additive and used in accordance with Good Manufacturing Practice (GMP). High solubility in water (about $150 \mathrm{~g} / \mathrm{L}$ at $25^{\circ} \mathrm{C}$ ) reduces its effectiveness in stabilizing fats and oils. Our research group had successfully synthesized D-isoascorbyl palmitate using immobilized lipase Novozym 435 as a biocatalyst. Low production efficiency of D-isoascorbyl palmitate is still a problem for industrial production due to the long reaction time of over $24 \mathrm{~h}$. In the present work, ultrasonic treatment was applied for accelerating the reaction process. The operation parameters were optimized to obtain the maximum D-isoascorbyl palmitate conversion rate by using a 5-level-4-factor Central Composite Design (CCD) and Response Surface Methdology (RSM). The reaction apparent kinetic parameters under the ultrasound treatment and mechanical shaking conditions were also determined and compared.

Results: Results showed that ultrasound treatment decreased the reaction time by over $50 \%$. D-isoascorbyl palmitate yielded to $94.32 \pm 0.17 \%$ and the productivity reached to $8.67 \mathrm{~g} \mathrm{~L}^{-1} \mathrm{~h}^{-1}$ under the optimized conditions as: $9 \%$ of enzyme load $(\mathrm{W} / \mathrm{W}), 61^{\circ} \mathrm{C}$ of reaction temperature, 1:5 of $\mathrm{D}$ - isoascorbic-to-palmitic acid molar ratio, and $137 \mathrm{~W}$ of the ultrasound power. The immobilized lipase Novozym 435 could be reused for 7 times with $65 \%$ of the remained D-isoascorbyl palmitate conversion rate. The reaction kinetics showed that the maximum apparent reaction rate $\left(v_{\max }\right)$ of the ultrasound-assisted reaction was 2.85 times higher than that of the mechanical shaking, which proved that ultrasound treatment significantly enhanced the reaction efficiency.

Conclusion: A systematic study on ultrasound-assisted enzymatic esterification for D-isoascorbyl palmitate production is reported. The results show a promising perspective of the ultrasound technique to reduce the reaction time and improve the production efficiency. The commercial D-isoascorbyl palmitate synthesis will be potentially realized due to this ultrasound-promoted esters synthesis method.
\end{abstract}

Keywords: D-isoascorbyl palmitate, Ultrasound treatment, Process optimization, Kinetic evaluation

\section{Background}

Lipid oxidation is the major cause for development of rancidity and off-flavor compounds in edible fatty products such as peroxides, ketones, aldehydes and oxyacids $[1,2]$. It will decrease the nutritional values of fats, oils and food materials and their shelf life. Therefore, to screen and/or develop the favorable additives for increasing the shelf of

\footnotetext{
* Correspondence: fengjiecui@163.com; sunwenjing1919@163.com 'School of Food and Biological Engineering, Jiangsu University, Zhenjiang 212013, P.R China

${ }^{2}$ Parchn Sodium Isovitamin C Co. Ltd, Dexing 334221, P.R China Full list of author information is available at the end of the article
}

edible fatty products and slowing the oxidative processes are the main challenges for the oil-based food industries [3].

D- isoascorbic acid (synonyms: Erythorbic acid, Daraboascorbic acid) is mainly used as a food antioxidant with the ability to prevent the food oxidation, decrease the color aroma and flavors, and block the carcinogen ammonium nitrite production during food manufacturing process [4]. Food and Drug Administration (FDA) had classified it as generally recognized as safe (GRAS) additives [5]. Now it is added in processed foods in accordance with Good Manufacturing Practice (GMP) [6,7].

$\mathrm{D}$-isoascorbic acid is freely soluble in water $(150 \mathrm{~g} / \mathrm{L}$ at $\left.25^{\circ} \mathrm{C}\right)$. However, the high hydrophilicity prevents its 
application in some fats, oil-based foods or cosmetics $[8,9]$. Converting D-isoascorbic acid into oil-soluble fatty acid ester is an effective solution to alter its solubility for enlarging its applications to the oil food, cosmetics and pharmaceutical fields. Recently, an erythorbyl fatty acid ester of erythorbyl laurate was obtained for improving the lipophilicity $[10,11]$. Our research group had also successfully synthesized D-isoascorbyl palmitate using immobilized lipase Novozym 435 as a biocatalyst and optimized the process parameters for obtaining the maximum Disoascorbyl palmitate yield [12]. However, the long reaction time over $24 \mathrm{~h}$ is still a drawback for industrial production and results in the low conversion efficiency. Hence, decreasing the reaction time and increasing the conversional efficiency are still a valuable consideration for D-isoascorbyl fatty acid ester synthesis.

Ultrasound has recently been applied for synthesizing the target compounds since it can increase the reaction process and improve the efficiency under the mild reaction conditions [13-17]. For example, the enzymaticcatalyzed transesterification process of glucose and divinyl dicarboxylates was significantly accelerated by using ultrasound assisted treatment [18]. Ultrasonication increased the biodiesel conversion to $85.5 \%$ from non-edible vegetable oil with the immobilized lipase (Chromobacterium viscosum) as a catalyst [19] and also decreased the reaction time of ascorbyl palmitate to $2 \mathrm{~h}$ with the conversion of about 27\% [20]. Ultrasound-induced cavitation bubbles collapse $[14,15]$ and efficient stirring or mixing of the layers might contribute to the increase of the chemical and/or enzymatic reactions rates in heterogeneous reactions $[16,17]$. However, few references are available for applying the ultrasound treatment in the isoascorbyl esters synthesis process.

In the present study, lipase-catalyzed synthesis of Disoascorbyl palmitate under the ultrasound treatment using immobilized lipase Novozym 435 as a biocatalyst was investigated. 5-level-4-factor Central Composite Design (CCD) and response surface methodology (RSM) were applied to find the relationships between reaction parameters and the $\mathrm{D}$-isoascorbyl palmitate conversion rate and maximizing the $\mathrm{D}$-isoascorbyl palmitate production efficiency. The process kinetics was finally developed for comparison of the ultrasound and mechanical shaking treatments.

\section{Results and discussion}

\section{Optimization of the conversion rate of D-isoascorbyl} palmitate under the ultrasound treatment

Firstly, the time course of lipase-catalyzed synthesis Disoascorbyl palmitate from D-isoascorbic and palmitic acid with ultrasound treatment was obtained to select the optimal reaction time for the next statistical experiments. As shown in Figure 1, the conversion rate increased

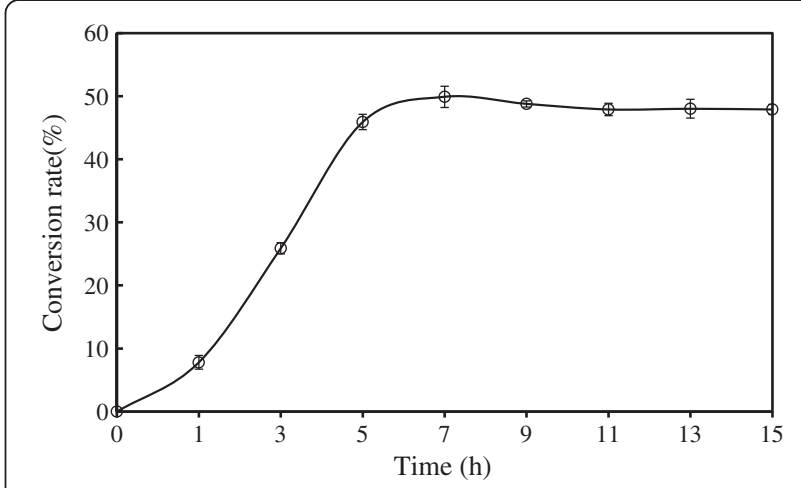

Figure 1 Time course of lipase catalyzed synthesis of Disoascorbyl palmitate under ultrasound-assisted treatment. (Enzyme load 10\% (weight \% of substrates); temperature: $50^{\circ} \mathrm{C}$; molar ratio: 1:4; acetone $20 \mathrm{~mL} ; 4 \AA$ A molecular sieves content: $50 \mathrm{~g} / \mathrm{L}$; Power: $180 \mathrm{~W}$ ).

rapidly to stable level of $48.68 \%$ during the 6 -h reaction when the reaction condition was set as following:enzyme load of $10 \%(\mathrm{w} / \mathrm{w})$, reaction temperature of $50^{\circ} \mathrm{C}$ and $\mathrm{D}$ isoascorbic-to-palmitic acid molar ratio of 1:4, acetone $20 \mathrm{~mL}, 50 \mathrm{~g} / \mathrm{L}$ of molecular sieves content and $180 \mathrm{~W}$ ultrasound power. Hence, 6-h of reaction time was selected for the remaining tests.

Response surface methodology is an empirical modeling technique used to evaluate the relationship between a set of controllable experimental factors and the observed results. In order to systemically find the relationships between reaction temperature, substrate molar ratio, enzyme load, and ultrasonic power for the synthesis of D-isoascorbyl palmitate, a 5-level-4-factor Central Composite Design (CCD) was applied with the 30 total experiments. Table 1 presented the experimental design and results of ultrasound assisted D-isoascorbyl palmitate synthesis using Novozym 435 as a biocatalyst within the 6$\mathrm{h}$ reaction. From Table 1, the run \#1 and \#16 had the minimum and maximum D-isoascorbyl palmitate conversion rates of $38.25 \%$ and $91.89 \%$, respectively. Other experimental runs presented the conversion rate of over $50 \%$.

Table 2 summarized the analysis of variance (ANOVA) for checking accuracy of the polynomial model. The model well presented the relationship between the responses and the variables with the model $F$-value of 20.67 and low $p$-value $(p<0.0001)$. Values of "Probability $>F$ " less than 0.05 indicate the model terms are significant. In general, higher $F$-value means the more significance of the corresponding coefficient [21]. From Table 2, the most influencing variables on the model response were $X_{2}$ (Molar ratio of D-isoascorbic to palmitic acid) and $\mathrm{X}_{4}$ (ultrasonic power).

The determination coefficient $\left(R^{2}\right)$ and adjusted determination coefficient (Adj. $R^{2}$ ) are commonly used to check the goodness of model. In the present study, $R^{2}$ of 0.9570 implied that $95.7 \%$ of the variation in the production yield could be explained by the regression model. The relatively 
Table 1 Experimental designs and the results of CCD

\begin{tabular}{|c|c|c|c|c|c|c|c|c|}
\hline \multirow{3}{*}{$\begin{array}{l}\text { Run } \\
1\end{array}$} & \multirow{3}{*}{$\begin{array}{l}\mathbf{A}(\mathbf{X} 1)^{\mathbf{a}} \\
-1\end{array}$} & \multirow{3}{*}{$\begin{array}{l}\mathrm{B}(X 2)^{\mathbf{b}} \\
-1\end{array}$} & \multirow{3}{*}{$\begin{array}{c}\mathrm{C}(\mathrm{X} 3)^{\mathrm{C}} \\
-1\end{array}$} & \multirow{3}{*}{$\begin{array}{l}D(X 4)^{d} \\
-1\end{array}$} & \multicolumn{4}{|c|}{ Conversion rate (\%) } \\
\hline & & & & & \multicolumn{4}{|c|}{ I II Average predicted } \\
\hline & & & & & 49.00 & 37.50 & $38.25 \pm 1.06$ & 40.81 \\
\hline 2 & 1 & -1 & -1 & -1 & 49.77 & 47.47 & $48.62 \pm 1.63$ & 49.85 \\
\hline 3 & -1 & 1 & -1 & -1 & 70.77 & 67.95 & $69.36 \pm 2.00$ & 69.55 \\
\hline 4 & 1 & 1 & -1 & -1 & 72.66 & 69.04 & $70.85 \pm 2.56$ & 73.65 \\
\hline 5 & -1 & -1 & 1 & -1 & 45.99 & 34.31 & $40.15 \pm 8.26$ & 46.72 \\
\hline 6 & 1 & -1 & 1 & -1 & 51.90 & 56.00 & $53.95 \pm 2.90$ & 57.31 \\
\hline 7 & -1 & 1 & 1 & -1 & 77.98 & 77.50 & $77.74 \pm 0.34$ & 75.84 \\
\hline 8 & 1 & 1 & 1 & -1 & 81.98 & 79.62 & $80.8 \pm 1.68$ & 81.80 \\
\hline 9 & -1 & -1 & -1 & 1 & 60.21 & 56.53 & $58.37 \pm 2.60$ & 61.21 \\
\hline 10 & 1 & -1 & -1 & 1 & 66.99 & 71.85 & $69.42 \pm 3.44$ & 73.48 \\
\hline 11 & -1 & 1 & -1 & 1 & 76.09 & 78.47 & $77.28 \pm 1.69$ & 76.08 \\
\hline 12 & 1 & 1 & -1 & 1 & 85.99 & 86.91 & $86.45 \pm 0.65$ & 83.42 \\
\hline 13 & -1 & -1 & 1 & 1 & 65.33 & 70.65 & $67.99 \pm 3.76$ & 67.34 \\
\hline 14 & 1 & -1 & 1 & 1 & 76.00 & 79.62 & $77.81 \pm 2.55$ & 81.86 \\
\hline 15 & -1 & 1 & 1 & 1 & 82.98 & 77.58 & $80.28 \pm 3.83$ & 82.59 \\
\hline 16 & 1 & 1 & 1 & 1 & 90.09 & 93.69 & $91.89 \pm 2.55$ & 91.48 \\
\hline 17 & -2 & 0 & 0 & 0 & 62.90 & 56.84 & $59.87 \pm 4.29$ & 57.35 \\
\hline 18 & 2 & 0 & 0 & 0 & 78.90 & 78.02 & $78.46 \pm 0.63$ & 75.27 \\
\hline 19 & 0 & -2 & 0 & 0 & 56.09 & 63.65 & $59.87 \pm 5.34$ & 51.05 \\
\hline 20 & 0 & 2 & 0 & 0 & 88.98 & 85.02 & $87.00 \pm 2.80$ & 90.11 \\
\hline 21 & 0 & 0 & -2 & 0 & 70.02 & 60.50 & $65.26 \pm 6.73$ & 63.39 \\
\hline 22 & 0 & 0 & 2 & 0 & 80.99 & 81.39 & $81.19 \pm 0.28$ & 77.36 \\
\hline 23 & 0 & 0 & 0 & -2 & 63.60 & 57.30 & $60.45 \pm 4.45$ & 55.54 \\
\hline 24 & 0 & 0 & 0 & 2 & 85.99 & 87.43 & $86.71 \pm 1.02$ & 85.07 \\
\hline 25 & 0 & 0 & 0 & 0 & 56.99 & 59.93 & $58.46 \pm 2.07$ & 58.43 \\
\hline 26 & 0 & 0 & 0 & 0 & 58.46 & 59.45 & $58.95 \pm 0.07$ & 58.43 \\
\hline 27 & 0 & 0 & 0 & 0 & 60.09 & 56.83 & $58.46 \pm 2.31$ & 58.43 \\
\hline 28 & 0 & 0 & 0 & 0 & 58.46 & 57.51 & $57.98 \pm 0.67$ & 58.43 \\
\hline 29 & 0 & 0 & 0 & 0 & 60.82 & 55.18 & $58.00 \pm 3.99$ & 58.43 \\
\hline 30 & 0 & 0 & 0 & 0 & 58.46 & 59.01 & $58.73 \pm 0.39$ & 58.43 \\
\hline
\end{tabular}

a: X1:Temperature; b: X2: Molar ratio (D-isoascorbic: palmitic acid);

c: X3: Enzyme load; d: X4: Ultrasound power.

low coefficient of variation value (C.V. \% =6.36) also proved the remarkable precision and reliability of the model. Neglecting the statistically insignificant terms $(P>0.05)$ and recalculating the coefficients, the quadratic models for $\mathrm{D}$-isoascorbyl palmitate conversion ratio in terms of coded factors are presented as follows:

$$
\begin{aligned}
Y= & 58.43+4.48 X_{1}+9.76 X_{2}+3.49 X_{3} \\
& +7.60 X_{4}-3.47 X_{2} X_{4}+1.97 X_{1}^{2}+3.04 X_{2}{ }^{2} \\
& +2.99 X_{3}^{2}+3.08 X_{4}{ }^{2}
\end{aligned}
$$

Where $Y$ is the response variable (D-isoascorbyl palmitate conversion rate, \%), and $X_{1}, X_{2}, X_{3}$, and $X_{4}$ are temperature, molar ratio of D-isoascorbic to palmitic acid, enzyme load and ultrasonic power, respectively. Figure 2 shows the experimental value and predicted conversion rate determined by the model Eq. (1), which indicated that the model was successful in capturing the relationship between actual and predicted responses.

3D surface plots of the predicted conversion rate of Disoascorbyl palmitate were shown in Figure 3. From these figures, the changes of D-isoascorbyl palmitate conversion rate with two variables can be easily obtained by fixing other variables constant at the center values (zero level).

Figure 3a shows the response surface plot on D-isoascorbyl palmitate conversion rate versus temperature and molar 
Table 2 ANOVA for response surface quadratic model

\begin{tabular}{|c|c|c|c|c|c|}
\hline Source & Sum of squares & df & Mean square & F -value & $p$-value \\
\hline Model & 5292.98 & 14 & 378.07 & 20.67 & $<0.0001^{* *}$ \\
\hline A & 481.91 & 1 & 481.91 & 26.35 & $0.0001^{* *}$ \\
\hline B & 2288.43 & 1 & 2288.43 & 125.12 & $<0.0001^{* *}$ \\
\hline C & 292.92 & 1 & 292.92 & 16.02 & $0.0012^{* *}$ \\
\hline D & 1384.64 & 1 & 1384.64 & 75.71 & $<0.0001^{* *}$ \\
\hline$A B$ & 24.27 & 1 & 24.27 & 1.33 & 0.2674 \\
\hline$A C$ & 2.41 & 1 & 2.41 & 0.13 & 0.7219 \\
\hline$A D$ & 10.44 & 1 & 10.44 & 0.57 & 0.4616 \\
\hline$B C$ & 0.15 & 1 & 0.15 & 0.01 & 0.9301 \\
\hline BD & 192.20 & 1 & 192.20 & 10.51 & $0.0055^{* *}$ \\
\hline$C D$ & 0.05 & 1 & 0.05 & 0.00 & 0.9599 \\
\hline$A^{2}$ & 106.51 & 1 & 106.51 & 5.82 & $0.0291^{*}$ \\
\hline$B^{2}$ & 253.27 & 1 & 253.27 & 13.85 & $0.0020^{* *}$ \\
\hline$C^{2}$ & 244.59 & 1 & 244.59 & 13.37 & $0.0023^{* *}$ \\
\hline$D^{2}$ & 259.45 & 1 & 259.45 & 14.19 & $0.0019^{* *}$ \\
\hline Residual & 274.34 & 15 & 18.29 & & \\
\hline Lack of fit & 273.59 & 10 & 27.36 & 182.63 & $<0.0001$ \\
\hline Pure error & 0.75 & 5 & 0.15 & & \\
\hline Cor total & 5567.33 & 29 & & & \\
\hline \multicolumn{2}{|c|}{ R-squared $=0.9570$} & \multicolumn{2}{|c|}{ Adj-squared $=0.9047$} & \multicolumn{2}{|c|}{ Ade precision $=16.756$} \\
\hline
\end{tabular}

**Significant at $1 \%$ level ${ }^{*}$ Significant at $5 \%$ level C.V. $\%=6.36$.

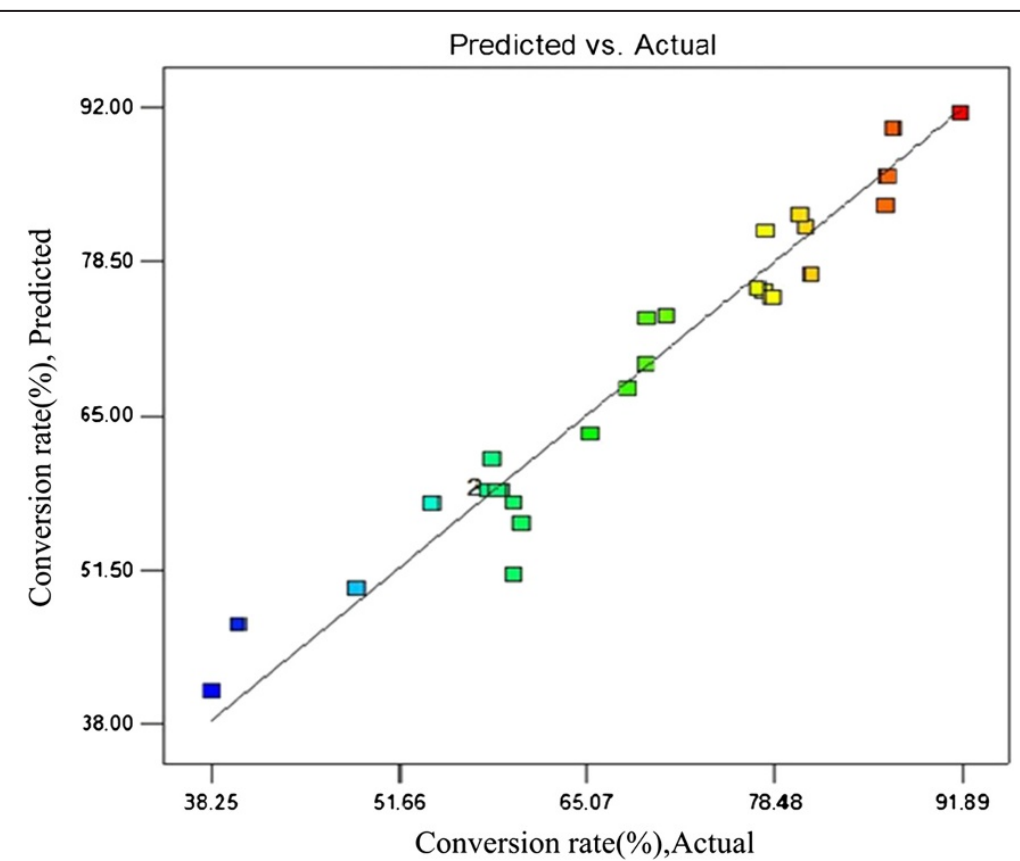

Figure 2 Plot of predicted and observed conversion rate (\%) of D-isoascorbyl palmitate. (—) Actual; ( $\square$ ) Predicted. 


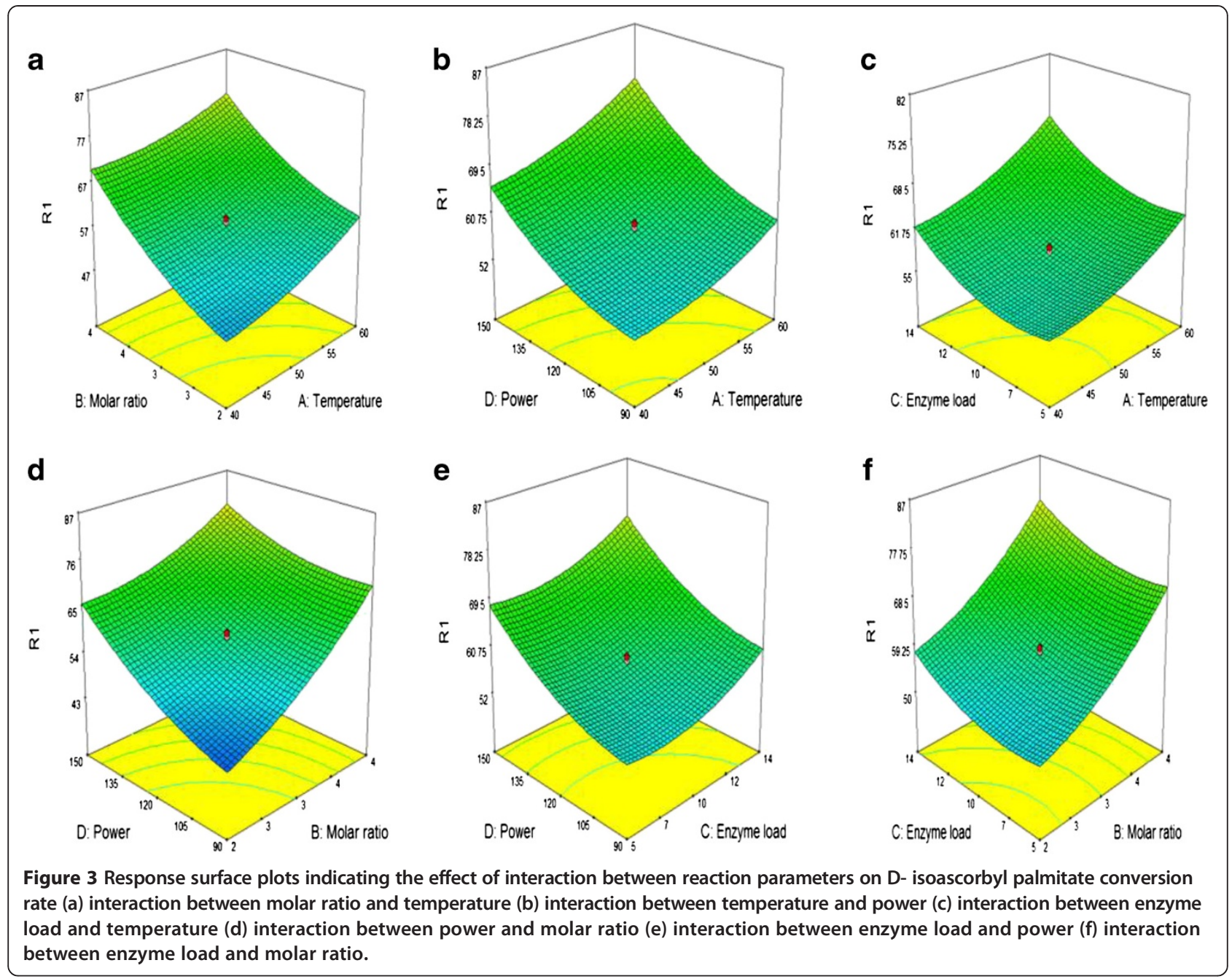

ratio of $\mathrm{D}$-isoascorbic to palmitic acid when the ultrasonic power and enzyme load were set at $120 \mathrm{~W}$ and 9.5\% (zero level), respectively. As shown the 3-D plot, the conversion rate of isoascorbyl palmitate was sensitive to the molar ratio of D-isoascorbic to palmitic acid even with a change from around $38 \%$ to $65 \%$. Figure $3 \mathrm{~b}$ shows that isoascorbyl palmitate conversion rate increased evidently with the increasing of ultrasonic power from $90 \mathrm{~W}$ to $180 \mathrm{~W}$. From Figure 3c, an increase in the conversion rate could be obviously achieved with the increase of enzyme load. Our previous study had found that high concentrations of lipase possibly decreased the isoascorbyl palmitate conversion rate due to the agglomeration of enzymes loaded at a higher amount [12]. As for the present study, ultrasound treatment possibly results in the more homogeneous reaction mixture and facilitates dispersion of lipase in substrates reducing the agglomeration [22]. In Figure 3d shows the response surface plot on D-isoascorbyl palmitate yield versus ultrasonic power and molar ratio of D-isoascorbic to palmitic acid when temperature and enzyme load were set at $50^{\circ} \mathrm{C}$ and $9.5 \%$ (zero level), respectively. The conversion rate changes significantly even when molar ratio of $\mathrm{D}$-isoascorbic to palmitic acid and ultrasonic power have the slight increase from 1:1 to $1: 4,90 \mathrm{~W}$ to $150 \mathrm{~W}$, respectively. The interaction between enzyme load and ultrasonic power while keeping the other parameters at their center values can be seen in Figure 3e. An increase in ultrasonic power improved the reaction yield for the minimum (0.5\%) and maximum (14\%) enzyme load. The results were in compliance with those reported by other groups [23-25]. The increase of ultrasonic power within the appropriate range could enhance the enzymatic reaction rate by enhancing the pulsating motions between the enzyme molecules and improving the binding/unbinding interactions with the reactants/substrates. The interactive effect between the enzyme load and molar ratio of $\mathrm{D}$-isoascorbic to palmitic acid can be found in Figure $3 \mathrm{f}$. The conversion rate reached to the maximum level of 77\% when the molar ratio was set as 4:1.

Using the Point Prediction function in the DesignExpert 7.1.1 software, the optimal conditions for obtaining the maximum $\mathrm{D}$ - isoascorbyl palmitate conversion 


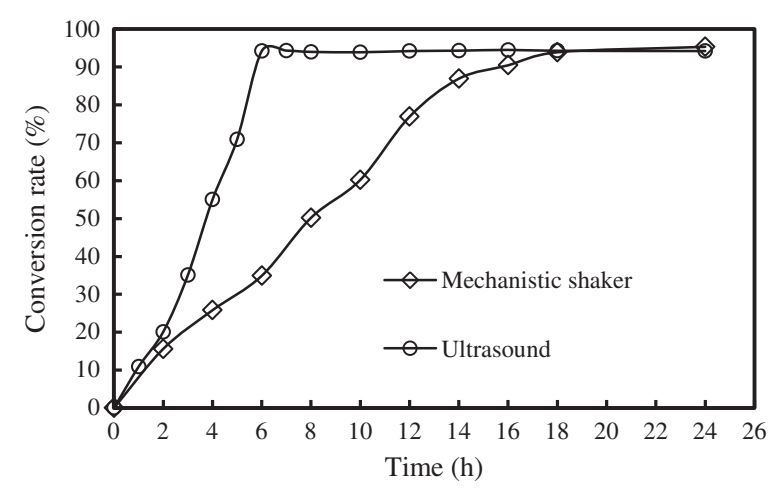

Figure 4 Comparison between ultrasound and mechanistic shaker on lipase-catalyzed synthesis of D- isoascorbyl palmitate under the optimal conditions. (The reaction condition of mechanistic shaker was enzyme load of $20 \%(\mathrm{w} / \mathrm{w})$, reaction temperature of $53^{\circ} \mathrm{C}$, D-isoascorbic-to-palmitic acid molar ratio of 1:4, acetone $20 \mathrm{~mL}, 40 \mathrm{~g} / \mathrm{L}$ of molecular sieves content, $150 \mathrm{rpm}$ speed. The reaction condition of ultrasound was enzyme load of $9 \%$ $(\mathrm{w} / \mathrm{W})$, reaction temperature of $61^{\circ} \mathrm{C}, \mathrm{D}$ - isoascorbic-to-palmitic acid molar ratio of 1:5, acetone $20 \mathrm{~mL}, 50 \mathrm{~g} / \mathrm{L}$ of molecular sieves content, ultrasound power of $137 \mathrm{~W}$ ).

rate were predicted as: enzyme load $9 \%(\mathrm{w} / \mathrm{w})$, reaction temperature $61^{\circ} \mathrm{C}$, D- isoascorbic-to-palmitic acid molar ratio $1: 5$ and ultrasound power of $137 \mathrm{~W}$. Under these conditions, the conversion rate reached to the maximum level of $95.09 \%$, which was higher than that of erythorbyl laurate reported by Lee et al. [11] with the conversion rate of $77.81 \%$ without ultrasound treatment.

To validate this prediction, the above reaction conditions were used for D- isoascorbyl palmitate synthesis for $6 \mathrm{~h}$ (Figure 4). The D- isoascorbyl palmitate conversion rate of $94.32 \pm 0.17 \%$ was finally obtained, which was very close to the predicted value of $95.09 \%$.

As for the D-isoascorbyl palmitate conversion rate, ultrasound treatment slightly increased to $94.32 \pm 0.17 \%$ compared to that of $94 \%$ with the mechanical shaking treatment. However, ultrasound treatment significantly decreased the reaction time from $12 \mathrm{~h}$ to $6 \mathrm{~h}$ to achieve the comparable conversion rate. The productivity for ultrasound-assisted D-isoascorbyl palmitate synthesis was about $8.67 \mathrm{~g} \mathrm{~L}^{-1} \mathrm{~h}^{-1}$, which was about 3.96 times of that obtained from mechanical shaking $\left(2.19 \mathrm{~g} \mathrm{~L}^{-1} \mathrm{~h}^{-1}\right)$.

\section{Enzyme reuse under the ultrasound-assisted conditions}

Enzyme recovery and reuse were still the main challenges during the bio-esterification reactions [26,27]. Therefore, the reuse of the immobilized lipase Novozym 435 was tested. From Figure 5, the conversion rates of D-isoascorbyl palmitate production was $65 \%$ and $15.02 \%$ after 7-time reuses under the ultrasound-assisted and mechanical shaking treatments, respectively.

\section{Kinetics of ultrasound-assisted lipase catalyzed D-isoascorbyl palmitate synthesis}

The ping-pong bi-bi kinetic mechanism illustrates alternate binding of substrates and release of products in a bi-substrate reaction with two formed products. It has been the most frequently used for describing the lipasescatalyzed esterification or transesterification process $[28,29]$. In this experiment, bi-substrate reaction of Disoascorbic acid and palmitic acid was involved. MichaelisMenten model still can be used in the present reaction by fixing the D-isoascorbic acid concentration fixed at $2.5 \mathrm{mM}$ [30]. The enzymatic reaction kinetic constant was calculated by changing the palmitic acid concentrations from $2.5 \mathrm{mM}$ to $20 \mathrm{mM}$. As shown in Figure 6, Lineweaver-Burk plots revealed that the Novozym 435-catalyzed esterification process of $\mathrm{D}$-isoascorbic acid and palmitic acid followed the classical Michaelis-Menten kinetics. The kinetic constants, including the apparent Michaelis constant, $K m$ (the Michaelis constant for palmitic acid) and the apparent maximum reaction rate $\left(v_{\max }\right)$, were

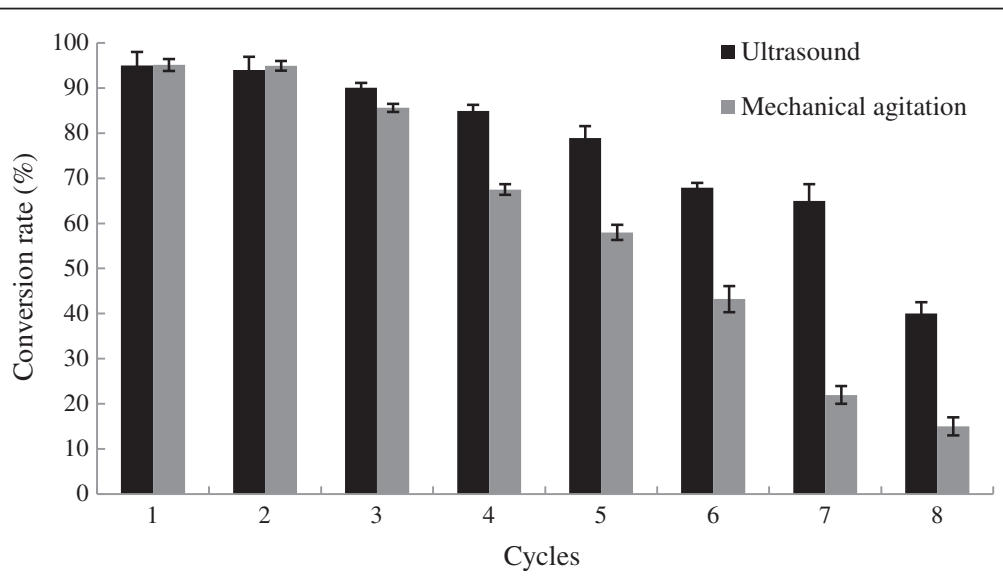

Figure 5 Comparison between ultrasound and mechanistic agitation on reusing of Novozyme 435 for D- isoascorbyl palmitate synthesis. 


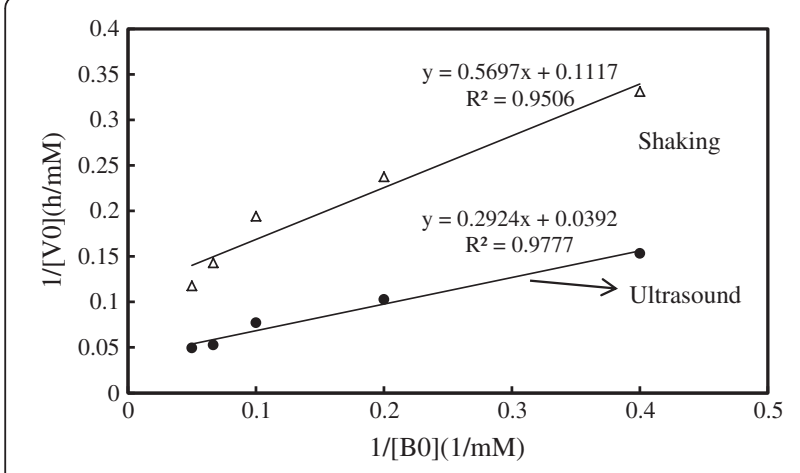

Figure 6 Lineweaver-Burk plot of reciprocal initial reaction rate against reciprocal palmitatic acid $\left(B_{0}\right)$ concentrations.

calculated according to equation (2) and the LineweaverBurk plot.

$$
\frac{1}{v}=\frac{K m}{v_{\max }} \cdot \frac{1}{[S]}+\frac{1}{v_{\max }}
$$

The curve of initial velocity and palmitic acid concentration shows good linearity. Under the ultrasoundassisted treatment, $\mathrm{Km}$ and $v_{\max }$ values were $7.49 \mathrm{mM}$ and $25.64 \mathrm{mM} \mathrm{h}^{-1}$, which were are 1.58 times and 2.85 times of those with the mechanical shaking treatment, respectively.

The comparison between ultrasound and mechanical shaking treatments was summarized in Table 3. These treatment methods resulted in the significant differences of reaction parameters, D-isoascorbyl palmitate productivity, and reaction rate. Further investigations will focus on the cost assessments of energy input and development of large scale ultrasound assisted reaction system.

\section{Experimental Section Materials}

D-Isoascorbic acid (purity $>99 \%$ ) was provided from Parchn Sodium Isovitamin C Co. Ltd (Dexing, Jiangxi, China). Palmitic acid, acetone, hexane and ethyl acetate were of analytical grade and obtained from Sinopharm Chemical Reagent Co., Ltd (Shanghai, China). Lipase of Novozym 435 (EC 3.1.1.3) from C. antarctica with the catalytic activity of $10000 \mathrm{PLU} / \mathrm{g}$ (the activity of PLU refers to the millimoles of Lauric acid isopropyl acetate synthesized per minute at $60^{\circ} \mathrm{C}$ ) were purchased from Novozymes (Denmark). This lipase has the optimal reaction temperature of $40-70^{\circ} \mathrm{C}$. Methanol was of HPLCgrade purchased from Tedia (Ohio, USA). All reagents were dehydrated by molecular sieve $4 \AA$ (Shanghai world molecular sieve Co., Ltd., Shanghai, China) and filtered using a membrane filter $(0.45 \mu \mathrm{m})$ prior to use.

\section{Ultrasound equipment}

The reaction was carried out in ultrasound equipment (Model KQ-300DE, Ningbo, China) with 4-Lworking volume (Figure 7). The ultrasound equipment was composed of water-bath, reactor and ultrasonic transducer. The ultrasound power was adjustable from $30 \mathrm{~W}$ to $200 \mathrm{~W}$.

\section{Esterification reaction}

The esterification reaction under the mechanical shaking treatment was conducted as described previously [12], the reaction solution included the D-isoascorbic acid $(2.5 \mathrm{mM})$ and palmitic acid with various molar ratios, the immobilized lipase with the concentration from 0.5 to 18.5 (w/w of the substrates amount), $50 \mathrm{~g} / \mathrm{L}$ of molecular sieve $4 \AA$. The synthesis reaction was conducted with temperature from $30^{\circ} \mathrm{C}$ to $70^{\circ} \mathrm{C}$ in a temperaturecontrolled shaker at the speed of $150 \mathrm{rpm}$.

As for the ultrasound treatment, the $150 \mathrm{~mL}$ flask was placed within the ultrasonic bath before the reaction was initiated as presented in Figure 7. The reaction solution and compositions are same with those of the mechanical shaking treatment. The reaction temperature was controlled by adjusting the water bath temperature from 20 to $80^{\circ} \mathrm{C}$. The ultrasonic power was set from $60 \mathrm{~W}$ to $180 \mathrm{~W}$.

Table 3 Comparison of D-isoascorbyl palmitate conversion performance between ultrasound and mechanical shaking conditions

\begin{tabular}{lll}
\hline Items & Ultrasound & Mechanical shaking \\
\hline Reaction time $(\mathrm{h})$ & 6 & 24 \\
Temperature $\left({ }^{\circ} \mathrm{C}\right)$ & 61 & 53 \\
Substrate molar ratio (D-isoascorbic: palmitic acid) & $1: 5$ & $1: 4$ \\
Enzyme load $(\mathrm{w} / \mathrm{w})$ & $9 \%$ & $20 \%$ \\
Conversion $(\%)$ & 94.32 & 95.32 \\
Productivity $\left(\mathrm{g} \mathrm{L}^{-1} \mathrm{~h}^{-1}\right)$ & 8.67 & 2.19 \\
Conversion after enzyme reuse $(8 \mathrm{cycles})$ & 40 & 15.02 \\
Apparent maximum reaction rate $\left(v_{\text {max }}\right)\left(\mathrm{mMh}^{-1}\right)$ & 25.64 & 9.01 \\
\hline
\end{tabular}




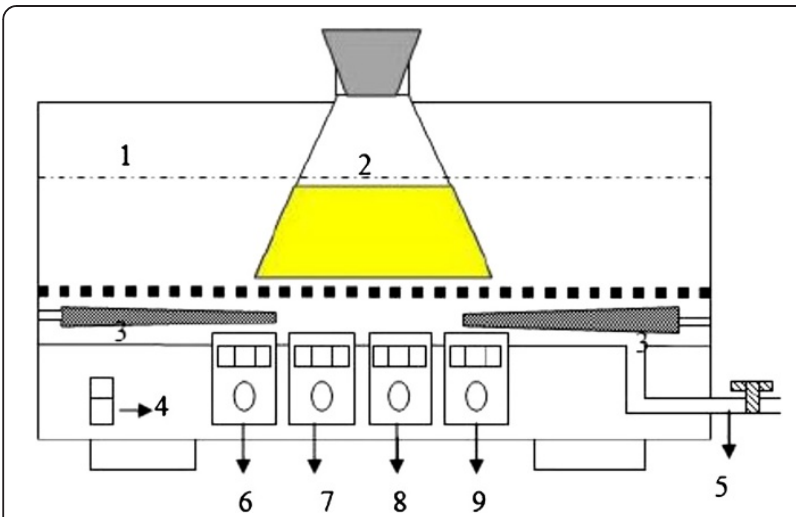

Figure 7 Ultrasound equipment: (1) water-bath; (2) reactor; (3) ultrasonic transducer; (4) power button; (5) water outlet; (6) temperature control panel; (7) ultrasonic timer control panel; (8) water level control panel; (9) ultrasonic output power button.

All the samples were taken at every $2 \mathrm{~h}$. The sampled reaction mixture was filtered through a membrane filter $(0.45 \mu \mathrm{m})$, and $20 \mu \mathrm{L}$ of each aliquot were injected into the HPLC for further analyzing the concentrations of the substrate isoascorbic acid and the produced Disoascorbyl palmitate.

\section{HPLC analysis}

Determining the concentrations of the produced Disoascorbyl palmitate, substrate isoascorbic acid was conducted using a Waters Alliance LC-20AT (SHIMADZU, Japan) liquid chromatography connected to a model 2996 (PDA) photo-diode array detector and controlled by LC Driver Ver.2.0 for Waters Empower ${ }^{\mathrm{rm}}$ software. The column equipped in the HPLC system was ZORBAX Eclipse XDB-C18 (150 mm $\times 4.6 \mathrm{~mm}, 5 \mu \mathrm{m}$, Torrance, CA, USA). The mobile phase was methanol/ water $(90: 10, \mathrm{v} / \mathrm{v})$ at $1.0 \mathrm{ml} / \mathrm{min}$ flow rate for $30 \mathrm{~min}$. Samples were injected automatically $(20.0 \mu \mathrm{L}$ of each other). The conversion rate (\%) was calculated by dividing the initial molar amount of D-isoascorbic acid by the produced molar amount of isoascorbyl palmitate.

\section{Experimental design}

In order to optimize the ultrasound assisted reaction conditions, a 5-level-4-factor Central Composite Design
(CCD) including 30 experiments was employed. A BoxBehnken factorial design was used for fitting a second order response surface [31].

Table 4 and Table 1 give the factors, their values, and the experimental design, respectively. A mathematical model was developed to describe the relationships between the response (the D-isoascorbyl palmitate conversion rate) and the varieties (ultrasound assisted reaction conditions) in second order equation. The conversion rate of $\mathrm{D}$ - isoascorbyl palmitate was multiply regressed with respect to the ultrasound assisted reaction conditions by using the software Design Expert 7.1.1(Stat-Ease, Minneapolis, MN, USA) as follow:

$$
Y=A_{0}+\sum A_{i} X_{i}+\sum A_{i i} X_{i}^{2}+\sum A_{i j} X_{i} X_{j}
$$

Where $Y$ is the measured response variable; $A_{o}, A_{i}, A_{i i}$, $\mathrm{A}_{\mathrm{ij}}$ are constant regression coefficients of the model, and $X_{i}, X_{j}(i=1,3 ; j=1,3, i \neq j)$ represent the independent variables (the ultrasound assisted reaction conditions) in the form of coded values. The accuracy and general ability of the above polynomial model could be evaluated by the determination coefficient $R^{2}$.

\section{Enzyme reuse}

For evaluating the lipase reuse times, the immobilized lipase was removed by vacuum filtration and the products were recovered for further analysis after finishing each batch reaction. The immobilized lipase was washed twice with $10 \mathrm{~mL}$ hexane, and then dried in an oven at $50^{\circ} \mathrm{C}$. The collected enzyme was used for the next run of catalyzing the esterification reaction.

\section{Determination of kinetic constants}

To determine the kinetics of the esterification reaction, reaction mixtures were prepared by a $\mathrm{D}$-isoascorbic acid (2.5 mM) with various palmitic acid (2.5-20 mM) in $20 \mathrm{~mL}$ of acetone at $50^{\circ} \mathrm{C} .10 \%$ (weight \% of substrates) of Novozym 435 was used with $180 \mathrm{~W}$ ultrasonic power. Initial reaction rate, expressed as $\mathrm{mM}$ produced $\mathrm{D}$ isoascorbyl palmitate per hour, were determined from time course of D-isoascorbyl palmitate concentration by regression analysis of the product concentration and determining the initial slope of the tangent to the curve.

Table 4 Process variables and their levels used in CCD

\begin{tabular}{|c|c|c|c|c|c|c|}
\hline \multirow[b]{2}{*}{ Independent variables } & \multirow[b]{2}{*}{ Coded symbols } & \multicolumn{5}{|c|}{ Levels } \\
\hline & & \multicolumn{5}{|c|}{$-2-1012$} \\
\hline Temperature $\left({ }^{\circ} \mathrm{C}\right)$ & $A\left(X_{1}\right)$ & 30 & 40 & 50 & 60 & 70 \\
\hline Molar ratio (D-isoascorbic: palmitic acid) & $B\left(X_{2}\right)$ & $1: 1$ & $1: 2$ & $1: 3$ & $1: 4$ & $1: 5$ \\
\hline Enzyme load (w/w) & $C\left(X_{3}\right)$ & 0.5 & 5 & 9.5 & 14 & 18.5 \\
\hline Ultrasonic power (W) & $\mathrm{D}\left(\mathrm{X}_{4}\right)$ & 60 & 90 & 120 & 150 & 180 \\
\hline
\end{tabular}




\section{Conclusions}

In this work, ultrasonic assistance of lipase (Candida antarctica; Novozym 435) catalyzed synthesis of the Disoascorbyl palmitate has been studied. Based on the statistical experimental results, the optimized reaction parameters were obtained as follows: enzyme load 9\% $(\mathrm{w} / \mathrm{w})$, reaction temperature $61^{\circ} \mathrm{C}, \mathrm{D}$ - isoascorbic-topalmitic acid molar ratio 1:5, and ultrasound power $137 \mathrm{~W}$ for 6-h reaction. Under the optimal conditions, ultrasound treatment yielded $94.32 \%$ of conversion rate and decreased the reaction time by over $50 \%$. The productivity was about $8.67 \mathrm{~g} \mathrm{~L}^{-1} \mathrm{~h}^{-1}$, which was 3.96 times higher than that with mechanical shaking system $\left(2.19 \mathrm{~g} \mathrm{~L}^{-1} \mathrm{~h}^{-1}\right)$. Ultrasound retained the lipase activity well. The catalytic reaction kinetics under an ultrasonic field agreed with Ping-Pong mechanism. The apparent maximum reaction rate $\left(v_{\max }\right)$ of the ultrasound treatment was 2.85 times higher than that of the mechanical shaking. Thus, the ultrasound treatment in the D-isoascorbyl palmitate synthesis leads to the improvement of process efficiency.

\section{Competing interests}

The authors declare that they have no competing interests.

\section{Authors' contributions}

FJ C and WJ S conceived of the study, participated in its design and coordination, and drafted the manuscript. HX Z performed experiments and analyzed results and helped to draft the manuscript. Z W, Q Z, SL Y and Y D performed partial experiments and analyzed results. All authors read and approved the manuscript.

\section{Acknowledgements}

This work was supported by funding from the National High Technology Research and Development Program (2012AA022103), China Postdoctoral Science Special Foundation (2013T60648), China Postdoctoral Science Foundation (2012M511222), 2012 Excellent Key Young Teachers Project of Jiangsu University, Student Research Grant Program of Jiangsu University (No 12A008), Advanced Programs of Jiangxi Postdoctoral Science Foundation ([2012]195 and 2013 KY17), Jiangxi Postdoctoral Science Foundation (2012 RC29), Science \& Technology Platform Construction Program (2010DTZ01900) and Priority Science and Technology Innovation Group Project of Jiangxi Province.

\section{Author details}

${ }^{1}$ School of Food and Biological Engineering, Jiangsu University, Zhenjiang 212013, P.R. China. ${ }^{2}$ Parchn Sodium Isovitamin C Co. Ltd, Dexing 334221, P.R. China. ${ }^{3}$ Jiangxi Provincial Engineering and Technology Center for Food Additives Bio-production, Xingangshan Town, Dexing 334221, P.R. China. ${ }^{4}$ Department of Pharmaceutical, Hebei Chemical and Pharmaceutical College, Shijiazhuang 050026, P.R. China.

Received: 9 August 2013 Accepted: 5 December 2013

Published: 9 December 2013

\section{References}

1. Karmee SK: Biocatalytic synthesis of ascorbyl esters and their biotechnological applications. App/ Microbiol Biotechnol 2009, 81:1013-1022

2. Estévez $M$, Ventanas $S$, Cava R: Protein oxidation in frankfurters with increasing levels of added rosemary essential oil: effect on color and texture deterioration. Food Chem 2007, 100:55-63.

3. Pokorny J, Yanishlieva N, Gordon M: Antioxidants in Food - Practical Applications. E-Publishing, Inc. England: Eds; 2001:7-21.
4. Alan AF: Final report on the safety assessment of ascorbyl palmitate, ascorbyl dipalmitate, ascorbyl stearate, erythorbic acid, and sodium erythorbate. Int J Toxicol 1999, 18:1-26.

5. U.S. Food and Drug Administration, Rockville, MD.U.S: http://www.accessdata. fda.gov/scripts/cdrh/cfdocs/cfcfr/CFRSearch.cfm?fr=182.3041.

6. FAO/WHO Food Standards: http:www.codexalimentarius.net/gsfaonline/ index.html.

7. Rehwoldt R: Tracking the use of antioxidants through industry surveys. Food Chem Toxicol 1986, 24:1039-1041.

8. Hui YH: Handbook of Food Science. E-Publishing, Inc. USA: Technology and Engineering; 2006:32-83.

9. Wescott CR, Klibanov AM: Solvent variation inverts substrate specificity of an enzyme. J Am Chem Soc 1993, 115:1629-1631.

10. Park KM, Lee DE, Sung $H$, Lee JH, Chang PS: Lipase-catalysed synthesis of erythorbyl laurate in acetonitrile. Food Chem 2011, 129:59-63.

11. Lee DE, Park KM, Choi SJ, Chang PS: Optimal production and structural characterization of erythorbyl laurate obtained through lipase-catalyzed esterification. Food Sci Biotechnol 2012, 21:1209-1215.

12. Sun WJ, Zhao HX, Cui FJ, Li YH, Yu SL, Zhou Q, Qian YG, Dong Y: D-isoascorbyl palmitate: lipase-catalyzed synthesis, structural characterization and process optimization using response surface methodology. Chem Cent J 2013, 7:114.

13. Lin G, Liu HC: Ultrasound-promoted lipase-catalyzed reactions. Tetrahedron Lett 1995, 36:6067-6068.

14. Cintas P, Luche JL: The sonochemical approach. Green Chem 1999, 1:115-125.

15. Chen $\mathrm{HC}$, Chen JH, Chang C, Shieh CJ: Optimization of ultrasound-accelerated synthesis of enzymatic caffeic acid phenethyl ester by response surface methodology. Ultrason Sonochem 2011, 18:455-459.

16. Yachmenev VG, Blanchard EJ, Lambert AH: Use of ultrasonic energy for intensification of the bio-preparation of greige cotton. Ultrason Sonochem 2004, 2:87-91.

17. Li C, Yoshimoto M, Ogata H, Tsukuda N, Fukunaga K, Nakao K: Effects of ultrasonic intensity and reactor scale on kinetics of enzymatic saccharification of various waste papers in continuously irradiated stirred tanks. Ultrason Sonochem 2005, 12:373-384

18. Xiao YM, Wu Q, Cai Y, Lina XF: Ultrasound-accelerated enzymatic synthesis of sugar esters in nonaqueous solvents. Carbohyd Res 2005, 340:2097-2103.

19. Kumar G, Kumar D, Poonam, Johari R, Singh CP: Enzymatic transesterification of Jatropha curcas oil assisted by ultrasonication. Ultrason Sonochem 2011, 18:923-927.

20. Lerin LA, Feiten MC, Richetti A, Toniazzo G, Treichel H, Mazutti MA: Enzymatic synthesis of ascorbyl palmitate in ultrasound-assisted system: process optimization and kinetic evaluation. Ultrason Sonochem 2011, 18:988-996.

21. Avramović JM, Stamenković OS, Todorović ZB, Lazić ML, Veljković VB: The optimization of the ultrasound-assisted base-catalyzed sunflower oil methanolysis by a full factorial design. Fuel Process Technol 2010, 91:155-157.

22. Liu YX, Jin QZ, Shan L, Liu YF, Shen W, Wang XG: The effect of ultrasound on lipase-catalyzed hydrolysis of soy oil in solvent-free system. Ultrason Sonochem 2008, 15:402-407.

23. Badday AS, Abdullah AZ, Lee KT: Optimization of biodiesel production process from Jatropha oil using supported heteropolyacid catalyst and assisted by ultrasonic energy. Renew Energy 2013, 50:427-432.

24. Sakakibara M, Wang D, Takahashi R, Takahashi K, Mori S: Influence of ultrasound irradiation on hydrolysis of sucrose catalyzed by invertase. Enzyme Microbiol Technol 1996, 18:444-448.

25. Brenelli ECS, Fernandes JLN: Stereoselective acylations of 1,2-azidoalcohols with vinyl acetate, catalyzed by lipase Amano PS. Tetrahedron: Asymmetry 2003, 14:1255-1259.

26. Martins AB, Graebin GN, Lorenzoni ASG, Lafuente RF, Rodrigues RC: Rapid and high yields of synthesis of butyl acetate catalyzed by Novozym 435: reaction optimization by response surface methodology. Process Biochem 2011, 46:2311-2316.

27. Veljković VB, Avramović JM, Stamenković OS: Biodiesel production by ultrasound-assisted transesterification: State of the art and the perspectives. Renew Sustain Energy Rev 2012, 16:1193-1209.

28. Yadav GD, Lathi PS: Synthesis of citronellol laurate in organic media catalyzed by immobilized lipase: kinetic studies. J Mol Catal B Enzym 2004, 27:113-119. 
29. Bezbradica D, Mijin D, Marinković S, Knezević Z: The Candida rugosa lipase catalyzed synthesis of amyl isobutyrate in organic solvent and solvent free system: a kinetic study. J Mol Catal B Enzym 2006, 38:11-16.

30. Zhang DH, Li YQ, Li C: Kinetics of enzymatic synthesis of L-ascorbyl acetate by Lipozyme TLIM and Novozym 435. Biotechnol Bioproc Eng 2012, 17:60-66.

31. Box GEP, Draper NR: Empirical Model-building and Response Surfaces. New York: Wiley; 1987.

doi:10.1186/1752-153X-7-180

Cite this article as: Cui et al:: Ultrasound-assisted lipase-catalyzed synthesis of D-isoascorbyl palmitate: process optimization and Kinetic evaluation. Chemistry Central Journal 2013 7:180.

\section{Publish with ChemistryCentral and every scientist can read your work free of charge}

"Open access provides opportunities to our colleagues in other parts of the globe, by allowing anyone to view the content free of charge."

W. Jeffery Hurst, The Hershey Company.

- available free of charge to the entire scientific community

- peer reviewed and published immediately upon acceptance

- cited in PubMed and archived on PubMed Central

- yours - you keep the copyright

Submit your manuscript here:

Submit your manuscript here:
http://www.chemistrycentral.com/manuscript/<smiles>c1ccccc1</smiles>

ChemistryCentral 